\title{
EDUKASI KESEHATAN DALAM UPAYA PENCEGAHAN DAN PENGENDALIAN KESEHATAN MATA PADA ANAK
}

DOI: https://doi.org/10.33024/jkpm.v4i4.4033

\author{
Romaden Marbun ${ }^{1}$, Wisoedhanie Widi², Vincensia Dea ${ }^{3 *}$ \\ 1,2,3 STIKes Panti Waluya Malang \\ Disubmit: 15 Maret 2021 Diterima: 07 April $2021 \quad$ Diterbitkan: 03 Agustus 2021 \\ Email Korespondensi: vincensiadhea@yahoo.com
}

\begin{abstract}
ABSTRAK
Anak adalah tunas, potensi, dan generasi muda penerus cita-cita perjuangan bangsa, memiliki peran strategis dan mempunyai ciri dan sifat khusus yang menjamin kelangsungan eksistensi bangsa dan negara pada masa depan. Di Era 4.0 yang terjadi sekarang di dunia, banyak masyarakat yang beralih menuju dunia teknologi digital. Salah satu teknologi digital yang banyak dimanfaatkan oleh semua kalangan adalah gadget. Tidak terkecuali pemanfaatan gadget ini oleh anak-anak. Gadget akan mempengaruhi kondisi psiko-sosial pada anak, terlebih gadget juga akan berdampak buruk pada kesehatan anak. Dan tanpa disadari juga, karena terlalu seringnya mereka bermain dengan teknologi, mata sebagai indera penglihat manusia akan terpengaruh oleh radiasi yang ditimbulkan. Oleh karena itu, dengan dilakukannya pemberdayaan kader terkait kesehatan mata diharapkan peran kader dalam upaya pencegahan dan pengendalian kesehatan mata pada anak dapat berjalan optimal. Program kemitraan ini bertujuan untuk meningkatkan pemahaman kader terhadap upaya pencegahan dan pengendalian kesehatan mata pada anak. Target utama program ini adalah kader kesehatan di Dusun Sukosari, Desa Pandansari, Kecamatan Poncokusumo, Kabupaten Malang. Kegiatan ini meliputi survei awal terkait kesehatan mata pada anak, dan melaksanakan penyuluhan tentang upaya pencegahan dan pengendalian kesehatan mata pada anak dengan menggunakan metode penyuluhan dan diskusi interaktif. Hasil dari kegiatan pengabdian masyarakat ini adalah adanya peningkatan pemahaman kader kesehatan terkait Penyakit Mata khususnya upaya dalam pencegahan dan pengendalian penyakit mata pada lansia di Dusun Sukosari, Desa Pandansari, Kecamatan Poncokusumo, Kabupaten Malang.

Kata Kunci : Anak, Indera Penglihatan, Kesehatan Mata
\end{abstract}

\begin{abstract}
Children are the shoots, potentials, and the next generation of the ideals of the nation's struggle, have a strategic role and have special characteristics and traits that ensure the continuity of the existence of the nation and the country in the future. In era 4.0 that is happening now in the world, many people are turning towards the world of digital technology. One of the digital technology that is widely utilized by all circles is gadgets. There is no exception to the use of this gadget by children. Gadgets will affect psycho-social conditions in children, especially gadgets will also adversely affect the health of the child. And unwittingly, too, because too often they play with technology, the eye as the
\end{abstract}


human sense of vision will be affected by the radiation caused. Therefore, with the empowerment of cadres related to eye health, it is expected that the role of cadres in efforts to prevent and control eye health in children can run optimally. This partnership program aims to improve cadres' understanding of efforts to prevent and control eye health in children. The main target of this program is health cadres in Sukosari Village, Pandansari Village, Poncokusumo District, Malang Regency. This activity includes initial surveys related to eye health in children, and conducting counseling on efforts to prevent and control eye health in children using counseling methods and interactive discussions. The result of this community service activity is an increase in the understanding of health cadres related to Eye Diseases, especially efforts in the prevention and control of eye diseases in the elderly in Sukosari Hamlet, Pandansari Village, Poncokusumo District, Malang Regency.

Keywords: Children, Sense of Vision, Eye Health

\section{PENDAHULUAN}

Di Era 4.0 yang terjadi sekarang di dunia, banyak masyarakat yang beralih menuju dunia teknologi digital. Segala usia memanfaatkan teknologi digital untuk kepentingan pribadi atau organisasi. Salah satu teknologi digital yang banyak dimanfaatkan oleh semua kalangan adalah gawai. Penggunaan gawai yang sering digunakan adalah smartphone atau Handphone. Smartphone adalah salah satu jenis telepon genggam yang memiliki kemampuan lebih canggih dibandingkan komputer (Oxforddictionaries 2018).

Gawai merupakan salah satu barang canggih yang menyajikan berbagai aplikasi baik itu jejaring sosial, media berita dan juga hiburan bagi para pengguna (Harfiyanto 2015). Pada masa kini, gawai banyak digunakan oleh semua kalangan baik orangtua, dewasa, remaja dan tidak terkecuali pemanfaatan gawai ini oleh anak-anak (Ilyas, 2012). Gawai menjadi daya tarik tersendiri untuk memanfaatkan waktu luang mereka. Gawai akan mempengaruhi kondisi psiko-sosial pada anak, terlebih gawai juga akan berdampak buruk pada kesehatan anak.

Orangtua menganggap bahwa gawai merupakan salah satu alay yang dapat digunakan untuk mendidik anak atau mempermudah komunikasi anak dengan orangtua atau oranglain. Tetapi tanpa disadari penggunaan gawai pada anak ini akan membuat anak tersebut menjadi kecanduan dengan banyaknya aplikasi yang menarik dan mempermudah anak-anak dalam kehidupannya. Dan tanpa disadari juga, karena terlalu seringnya mereka bermain dengan teknologi, mata sebagai indera penglihat manusia akan terpengaruh oleh radiasi yang ditimbulkan. Posisi tubuh yang kurang baik saat menggunakan gawai, intensitas pencahayaan yang kurang baik maka akan berdampak buruk terhadap kesehatan mata salah satunya yaitu penurunan ketajaman penglihatan (Ernawati 2015).

Menurut World Health Organization (2014) menyatakan bahwa 285 juta penduduk di dunia mengalami gangguan penglihatan . Gangguan penglihatan tersebut disebabkan oleh kelainan refraksi (myopia, hiperopia atau stigmatisme) sebesar $43 \%$, katarak yang idak bisa ditangani dengan operasi sebessar 33\% dan glaucoma sebesar 2\% (WHO, 2014). 
Peningkatan prevalensi gangguan mata pada anak menjadi ancaman yang serius dalam pembangunan, karena mengancam pertumbuhan ekonomi nasional. Oleh karena perlu adanya kader kesehatan dalam suatu desa guna membantu dalam peningkatan penyelenggaraan kesehatan. Pos pelayanan terpadu (posyandu) merupakan salah satu bentuk upaya peningkatan kesehatan yang bersumber daya masyarakat, dikelola dan diselenggarakan dari, oleh, untuk, dan bersama masyarakat dalam penyelenggaraan pembangunan kesehatan. (Iswarawanti, 2010; Suhat \& Hasanah, 2014).

Kader Posyandu merupakan jajaran pertama dalam menjangkau masyarakat, ketika tenaga kesehatan tidak ada atau ketika masyarakat sulit mendapatkan akses ke tenaga kesehatan. Kader kesehatan dapat menjadi perpanjangan tangan dalam meningkatkan pemahaman masyarakat tentang status kesehatan nya. Selain itu, kader posyandu juga merupakan jajaran terdepan dalam mentransfer pengetahuan, pemahaman dan keterampilan dalam menangani berbagai macam penyakit khususnya penyakit terkait gangguan mata, sehingga kader menjadi sangat penting untuk mendapatkan pemahaman tentang penyakit terkait kesehatan mata itu sendiri dan berkenaan dengan upaya pencegahan dan pengendalian penyakit gangguan mata khususnya pada anak.

Desa Pandansari merupakan salah satu desa yang terletak di Kecamatan Poncokusumo, Kabupaten Malang. Secara geografis, desa Pandansari terletak di lereng gunung Semeru dan gunung Bromo yang merupakan gugusan gunung aktif di wilayah provinsi Jawa Timur. Desa Pandansari berbatasan langsung dengan Perhutani pada sisi Timur, desa Sumberejo pada sisi Selatan, dan desa Ngadireso pada sisi Barat. Desa Pandansari terdiri dari tiga dusun, yaitu Dusun Pandansari Krajan, Dusun Wonosari, dan Dusun Sukosari.

Menurut wawancara awal dengan kepala desa Pandansari pada tahun 2020 awal didaptkan data jumlah penduduk di desa Pandansari berjumlah 7000 jiwa, dengan rincian 3.644 jiwa laki-laki, dan 3.356 jiwa perempuan. Penduduk tersebut terbagi dalam 18 RW dan 65 RT. Jumlah penduduk terbanyak terdapat di dusun Pandansari Krajan sejumlah $1.500 \mathrm{KK}$, dengan jumlah penduduk sebanyak 4.900 jiwa. Dua dusun yang lain memilki jumlah penduduk yang lebih sedikit, yaitu $380 \mathrm{KK}$ pada dusun Wonosari, dengan jumlah penduduk sebanyak 1.153 jiwa, dan 303 KK di dusun Sukosari dengan jumlah penduduk sebanyak 938 jiwa. Pendidikan akhir yang dimiliki penduduk di Desa Pandansari bervariasi. Mayoritas pendidikan formal yang ditempuh oleh penduduk di Desa Pandansari adalah Sekolah Dasar (SD) sebanyak 3.752 jiwa, berpendidikan SLTP sebanyak 676 jiwa, berpendidikan SLTA sebanyak 152 jiwa, lulus sarjana sebanyak 51 jiwa, dan sisanya atau sebanyak 762 jiwa tidak pernah menempuh pendidikan formal.

Program kemitraan ini bertujuan untuk meningkatkan pemahaman kader terkait penyakit mata khususnya dalam upaya pencegahan dan pengendalian penyakit gangguan mata pada anak terutama di Dusun Sukosari. Dengan adanya pemberdayaan kepada kader kesehatan di dusun Sukosari terkait pencegahan dan pengendalian penyakit mata diharapkan pemahaman kader kesehatan terkait upaya pencegahan dan pengendalian penyakit mata dapat meningkat sehingga mampu ikut berperan dalam mencegah dan menurunkan 
prevalensi penyakit gangguan mata pada anak di Dusun Sukosari, Desa Pandansari, Kecamatan Poncokusumo, Kabupaten Malang.

\section{MASALAH}

Desa Pandansari rutin menghadapi kejadian tanah longsor, banjir, dan puting beliung setiap tahunnya, termasuk munculnya retakan pada rumah warga akibat pergeseran tanah. Kontur tanah di desa Pandansari cenderung berbukit dengan komposisi tanah berpasir. Tanah berpasir menimbulkan permasalahan tersendiri, yaitu tanah longsor yang terjadi baik saat musim penghujan maupun kemarau. Tanah longsor akan memutuskan akses jalan dari desa Pandansari ke arah Poncokusumo. Hal ini akan berdampak pada hal ekonomi dan kesehatan masyarakat. Saat terjadi tanah longsor, akses jalan akan tertutup sehingga petani tidak dapat mengirimkan hasil bumi ke kota dan sulit untuk mencari fasilitas pelayanan kesehatan. Selain tanah longsor, desa Pandansari juga termasuk dalam area yang terdampak ketika terjadi letusan gunung Bromo dan Semeru.

Akses menuju tenaga kesehatan atau fasilitas kesehatan tidak terlalu menjadi masalah bagi penduduk dusun Pandansari Krajan karena perawat desa dan bidan terletak pada dusun ini. Namun akses kepada tenaga kesehatan akan lebih sulit didapat bagi penduduk dusun Sukosari. Hal ini disebabkan karena lokasi dusun Sukosari yang terletak lebih jauh jika dibandingkan dengan dua dusun lainnya. Jalan yang naik turun dan sempit karena terletak di area perbukitan mempersulit warga untuk mendapat pelayanan kesehatan. Dua RT pada dusun Sukosari letaknya cukup jauh dari lima RT lainnya dalam satu desa, kedua RT tersebut juga dilalui oleh sungai musiman. Sehingga pada saat sungai meluap dimusim penghujan, masyarakat kedua RT akan terisolir dari lokasi lainnya. Kondisi ini tentu saja akan menyulitkan penduduk untuk mendapatkan akses ke tenaga kesehatan atau fasilitas pelayanan kesehatan.

Alasan tim melakukan sosialisasi dan pemberdayaan terhadap kader kesehatan posyandu di Dusun Sukosari ini karena lokasi dusun yang lebih jauh dari pada dusun lainnya di Desa Pandansari sehingga masyarakat terutama anak-anak minim jangkauan dan pengamatan oleh tenaga kesehatan untuk memantau warga Dusun Sukosari.

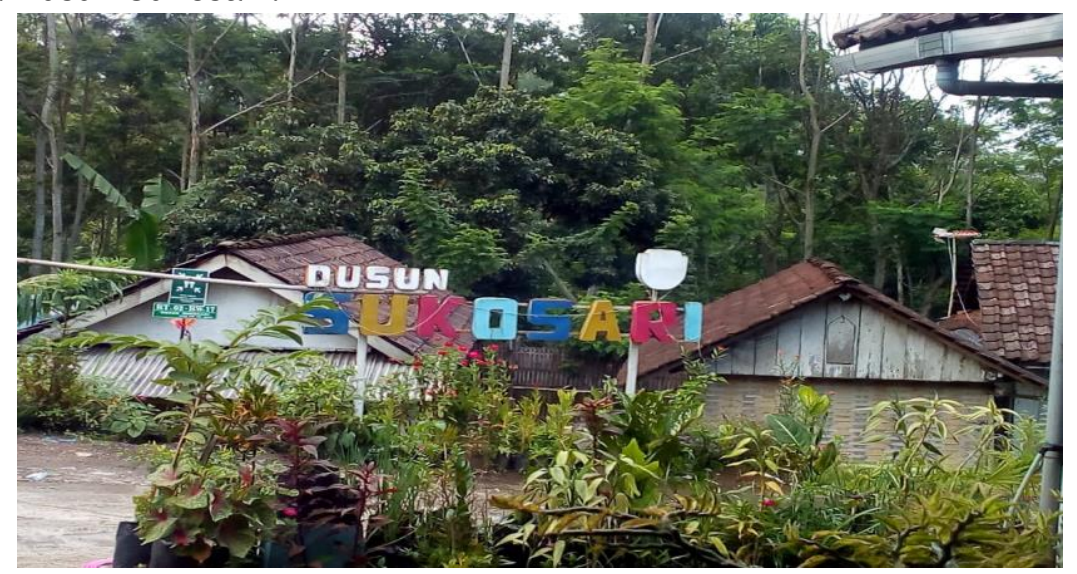

Gambar 2.1 Lokasi Dusun Sukosari, Desa Pandansari, Kecamatan Poncokusumo, Kabupaten Malang 


\section{METODE}

Metode pelaksanaan yang diterapkan untuk mencapai tujuan dari program kemitraan ini adalah dengan melakukan penyuluhan dan diskusi interaktif. Penyuluhan diberikan oleh 3 pemateri kepada 15 kader kesehatan yang ada di Dusun Sukosari dengan masing-masing diberikan waktu 45 menit. Kegiatan dilaksanakan pada pagi hari pukul 10.00 WIB sampai dengan 13.00 WIB. Adapun materi yang diberikan adalah materi terkait pentingnya kesehatan mata, anatomi mata, dan penyakit-penyakit pada mata pada anak dan Upaya Pencegahan dan Pengendalian kesehatan mata pada anak. Selain memaparkan materi yang diberikan pada saat penyuluhan, pemateri juga membagikan media bantu seperti leaflet pentingnya kesehatan mata pada anak kepada para kader kesehatan.

Kegiatan ini dilakukan untuk meningkatkan pemahaman kader terkait upaya pencegahan dan pengendalian penyakit gangguan mata khususnya pada anak. Untuk menilai tingkat pemahaman kader terkait penyakit gangguan mata khususnya upaya pencegahan dan pengendalian penyakit gangguan mata pada anak, maka sebelum diberikan penyuluhan, para kader akan dilakukan pretest dan di akhir penyuluhan akan dilakukan posttest. Secara garis besar, pertanyaan yang dicantumkan pada pretest dan posttest adalah pertanyaan seputar mata, kesehatan mata, anatomi mata, dan penyakit-penyakit pada mata, dampak gangguan mata dan Upaya Pencegahan dan Pengendalian kesehatan mata pada anak.

\section{HASIL DAN PEMBAHASAN}

Program Kemitraan yang dilaksanakan di Dusun Sukosari, Desa Pandansari, Kecamatan Poncokusumo, Kabupaten Malang ini mendapat kan respon yang positif dari Puskesmas Poncokusumo dan Perangkat Desa Pandansari, Khususnya Para Kader Kesehatan di Dusun Sukosari. Sasaran utama program ini adalah kader kesehatan yang ada di Dusun Sukosari, Ds.Pandansari, Kec. Poncokusumo, Kabupaten Malang. Pra kegiatan ini dilaksanakan pada tanggal 5 Januari 2020 bersamaan dengan dilaksanakannya Posyandu di Dusun Sukosari.

Pra kegiatan yang dilakukan adalah melakukan koordinasi kepada perwakilan kader kesehatan, diskusi terkait penyakit gangguan mata pada anak dan melakukan sosialisasi kegiatan penyuluhan kepada para kader di Dusun Sukosari yang berjumlah 15 orang. Pelaksanaan kegiatan penyuluhan dilaksanakan sebanyak 2 (dua) kali yaitu pada tanggal 12 dan 19 Januari 2020 di rumah Posyandu dusun Sukosari dengan metode ceramah dan diskusi inetraktif bersama dengan 15 kader posyandu kesehatan.

Kegiatan Penyuluhan I disampaikan oleh 1 pemateri dari dosen Prodi D3 Keperawatan dengan rincian materi sebagai berikut: Aktivitas Anak, Indera pada manusia, Indera penglihatan dan anatomi mata. Sedangkan, kegiatan penyuluhan II disampaikan oleh 2 pemateri yaitu Dosen dari Program Studi DIV Manajemen Informasi Kesehatan dengan materi penyakit-penyakit pada mata, pentingnya kesehatan mata dan Upaya Pencegahan dan Pengendalian kesehatan mata pada anak. 


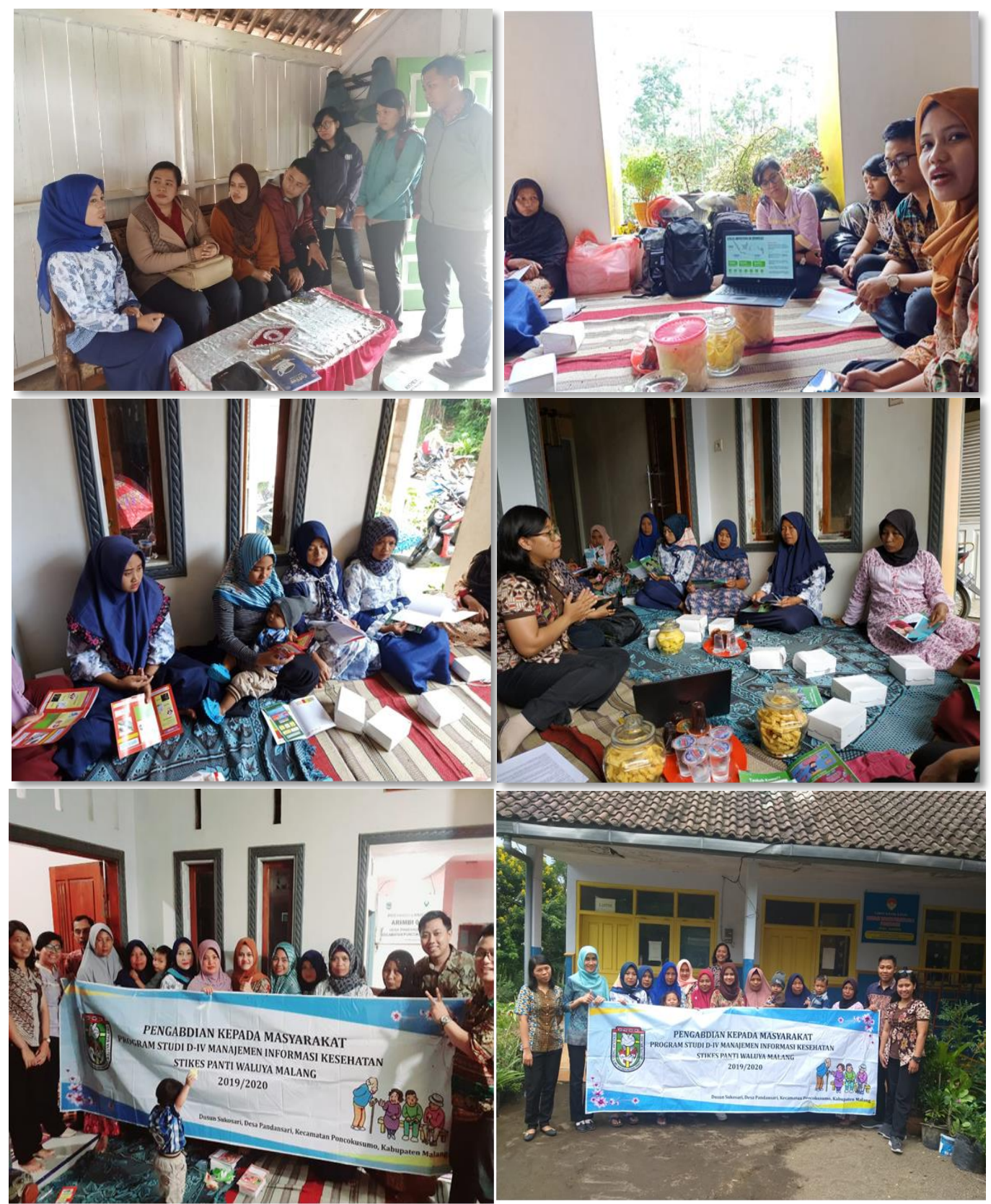

Gambar 3.1 Foto Kegiatan PKM

\section{KESIMPULAN}

Kegiatan Pengabdian Kepada Masyarakat yang dilaksanakan di Dusun Sukosari, Desa Pandansari, Kecamatan Poncokusumo, Kabupaten Malang terlaksana sesuai dengan rencana yang telah disusun, meliputi pemberian edukasi dengan metode ceramah dan diskusi interaktif pada 15 kader kesehatan yang ada di dusun Sukosari. Edukasi kesehatan pada kader kesehatan di Dusun Sukosari, Desa Pandansari, Kecamatan Poncokusumo, Kabupaten Malang mengenai pentingnya pencegahan penyakit mata pada anak menunjukkan adanya peningkatan pemahaman para kader kesehatan terkait kesehatan mata, termasuk didalamnya adalah bagaimana melakukan upaya pencegahan dan pengendalian penyakit gangguan mata pada anak. 


\section{DAFTAR PUSTAKA}

Erin, S. (2012, Oktober 29). Gangguan dan Penyakit Akibat Kemajuan Teknologi Masa Kini. Available from:http://sharingdisinicom/2012/10/29/gangguan-dan-penyait-akibatkemajuan-teknologimasa-kini/.

Ernawati, Widea. (2015). Pengaruh Penggunaan Gadget Terhadap Penurunan Tajam Penglihatan Pada Anak Usia Sekolah (6-12 Tahun) Di Sd Muhammadiyah 2 Pontianak Selatan. Jurnal Proners,3(1), 5-6.

Harfiyanto, D., Budi Utomo, C., \& Budi, T. (2015). Pola Interaksi Sosial Siswa Pengguna Gadget di SMAN 1 Semarang. Journal of Educational Social Studies, 4(1). https://doi.org/10.15294/jess.v4i1.6859

Ilyas, S. (2012). Ilmu Penyakit Mata Untuk Dokter Umum Dan Mahasiswa Kedokteran. Jakarta: Sagung Seto.

Isfandiyari A. (2014). Hubungan faktor Risiko Miopia pada anak usia 7-11 Tahun Siswa SDN Tembalang Kota Semarang.

Ismawati, Cahyo, dkk. (2010). Posyandu \& Desa Siaga. Yogyakarta : Nuha Medika.

Iswarawanti, D. N. (2010). Kader posyandu: Peranan dan tantangan pemberdayaannya dalam usaha peningkatan gizi anak di Indonesia. Jurnal Manajemen Pelayanan Kesehatan, 13(4), 169-173.

Maharani, D. (2011). Pengaruh Kebiasaan Anak Dalam Menggunakan Handphone Terhadap Kesehatan Mata. KTL : SMA Negeri 1 Jember.

Mediasyifa. (2014). Pengaruh Penggunaan Gadget Pada Remaja Terhadap Interaksi Sosial Remaja. Bogor : Institut Pertanian Bogor.

Oxforddictionaries. (2018, Oktober 15). Diakses dari Http://www.oxforddictionaries.com/definiti on/english/smartphone.

Sarasningrat MI. (2011). Gambaran Tingkat Pengetahuan dan Sikap Siswa SD Islam Ruhama Cireudeu Kelas 5 dan 6 terhadap Miopia dan Faktor yang Mempengaruhinya tahun 2011: Universitas Islam Negeri Syarif Hidayatullah.

Suhat \& Hasanah, R. (2014). Faktor-Faktor yang berhubungan dengan keaktifan kader dalam kegiatan posyandu (Studi di Puskesmas Palasari Kabupaten Subang). Jurnal Kesehatan Masyarakat, 10(1), 73-79.

World Health Organization. (2014, September 6). WHO _ Visual impairment and blindness Fact Sheet No.282. Diakses dari: http://www.who.int/mediacentre/factsheets/fs282/en/ 